\title{
Histochemistry of Pancreas in Large White Yorkshire and Desi Pigs
}

\author{
K. Iniyah*, S. Jayachitra, K. Balasundaram and A. Arulmozhi \\ Department of Veterinary Anatomy, Veterinary College and Research Institute, Namakkal, \\ Tamil Nadu, India \\ *Corresponding author
}

\begin{abstract}
A B S T R A C T
Keywords

Pancreas, histochemistry, Islets of Langerhans

Article Info

Accepted:

24 May 2018

Available Online:

10 June 2018

The pancreas is a unique and composite digestive gland consisting of exocrine part of acini and endocrine part of islets of Langerhans. The pancreas were collected from five age groups viz., four, six, eight, ten months and adult in large white Yorkshire and also from adult desi pigs. Histochemical study revealed that the duct epithelium showed strong PAS reaction and weak reaction to acid mucopolysaccharides. Numerous tyrosine and lysine containing proteins were observed in the pancreatic parenchyma. Positive reaction for lipid was noticed in the sub capsular and interlobular connective tissue of pancreas in both large white Yorkshire and desi pigs. Likewise, all the acinar, ductal epithelium and cells of islets of Langerhans showed positive ribonucleic acid reaction. Acid phosphatase, alkaline phosphatase and non-specific esterase activities were observed in acinar cells and epithelial cells of pancreatic ducts.
\end{abstract}

\section{Introduction}

The pancreas is a unique and composite digestive gland which consists of both exocrine and endocrine parts. The exocrine pancreatic acini secrete digestive enzymes along with many electrolytes (Budipitojo et al., 2016) and the endocrine, islets of Langerhans is responsible for the synthesis of regulatory hormones such as insulin and glucagon.

As transplantation of porcine islets of Langerhans is considered to be a possible alternative for clinical islet transplantation in humans (Hilling et al., 2009), the present study was carried out in large white Yorkshire and desi pigs.

\section{Materials and Methods}

The pancreas was collected from apparently healthy large white Yorkshire and desi pigs which were slaughtered at local slaughter house, Namakkal and at the Department of Meat science, Veterinary College and Research Institute, Namakkal. The pancreas of large white Yorkshire were collected from five age groups viz., four, six, eight, ten months, adult and the pancreas of desi pigs were collected from adult animals. Each group comprised of six samples of either sex.

Immediately after slaughter, the pancreas was removed, washed in normal saline and mopped with blotting paper. Then the tissues from splenic, duodenal and connecting lobes 
of pancreas of large white Yorkshire and desi pigs were collected and fixed in various standard fixatives viz., $10 \%$ neutral buffered formalin, Bouin's fluid and formal calcium. Fixed tissues were processed through ascending grades of alcohol, cleared in xylene and embedded in paraffin wax at $58-60^{\circ} \mathrm{C}$ as per the method described by Luna (1968).

Sections of 3-5 $\mu \mathrm{m}$ thickness were made by using Leica Rotary microtome. Histochemistry were studied with the help of Leica Image Analyzer. Freshly collected unfixed frozen tissues of 15-20 $\mu$ m thickness were utilized for demonstration of lipids and enzymes.

\section{Results and Discussion}

\section{Histochemistry}

Histochemical study revealed the following features in the pancreas of large white Yorkshire and desi pigs. In all the age groups studied, the duct epithelium of pancreas showed strong PAS positive reaction (Fig.1) and weak acid mucopolysaccharide reaction
(Fig. 2) as stated by Deprem et al., (2015) in goose and McMinn and Kugler (1961) in dog and cat.

Numerous tyrosine containing proteins were observed in the pancreatic parenchyma of large white Yorkshire and desi pigs. All the acinar cells showed positive reaction for lysine in Ninhydrin Schiff method. In contrary, Hamodi et al., (2013) observed moderate to weak negative reaction for proteins in the pancreatic cells of guinea fowl and common gull.

In both the pigs, all the nuclei of acinar, ductal epithelial and cells of islets of Langerhans showed positive ribonucleic acid reaction (Bancroft and Stevens, 1996).

The positive reaction for lipids was noticed in the sub capsular and interlobular connective tissue of pancreas in both large white Yorkshire and desi pigs. This is in accordance with the findings of Singh and Gupta (1995) in buffalo. In contrast, Hamodi et al., (2013) reported negative reaction for lipids in pancreas of guinea fowl and common gull.

Fig.1 Pancreatic duct epithelium showing strong PAS positive reaction

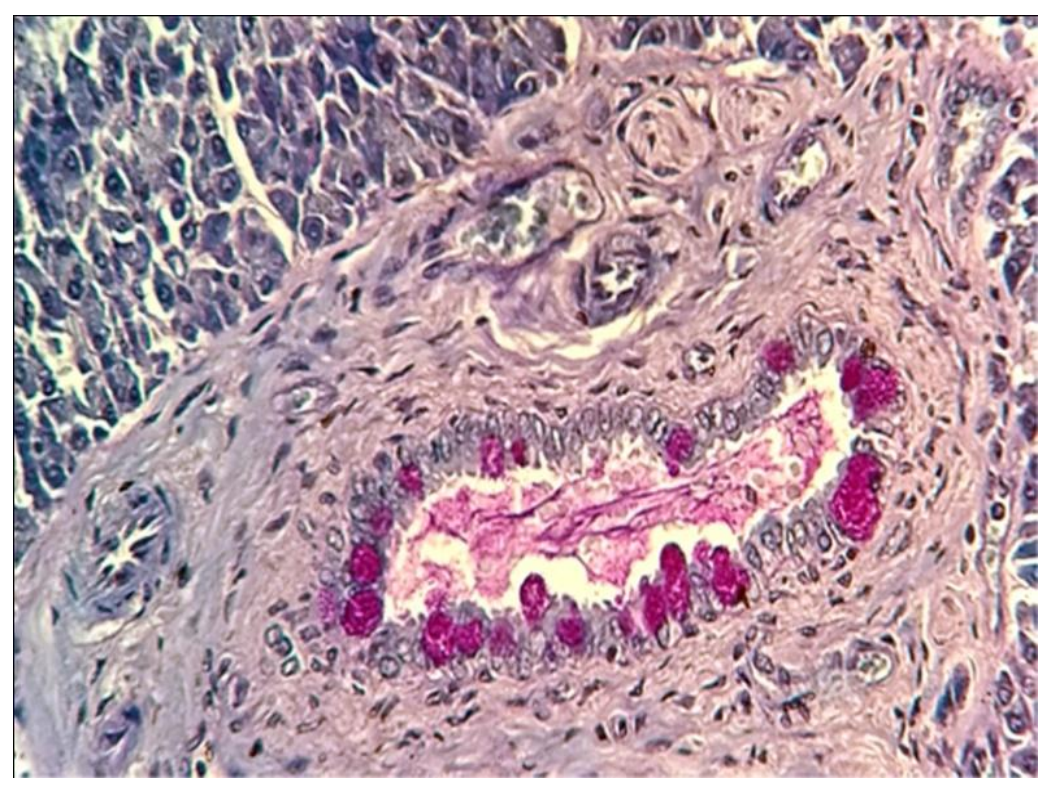


Fig.2 Pancreatic duct epithelium showing weak mucopolysaccharide reaction

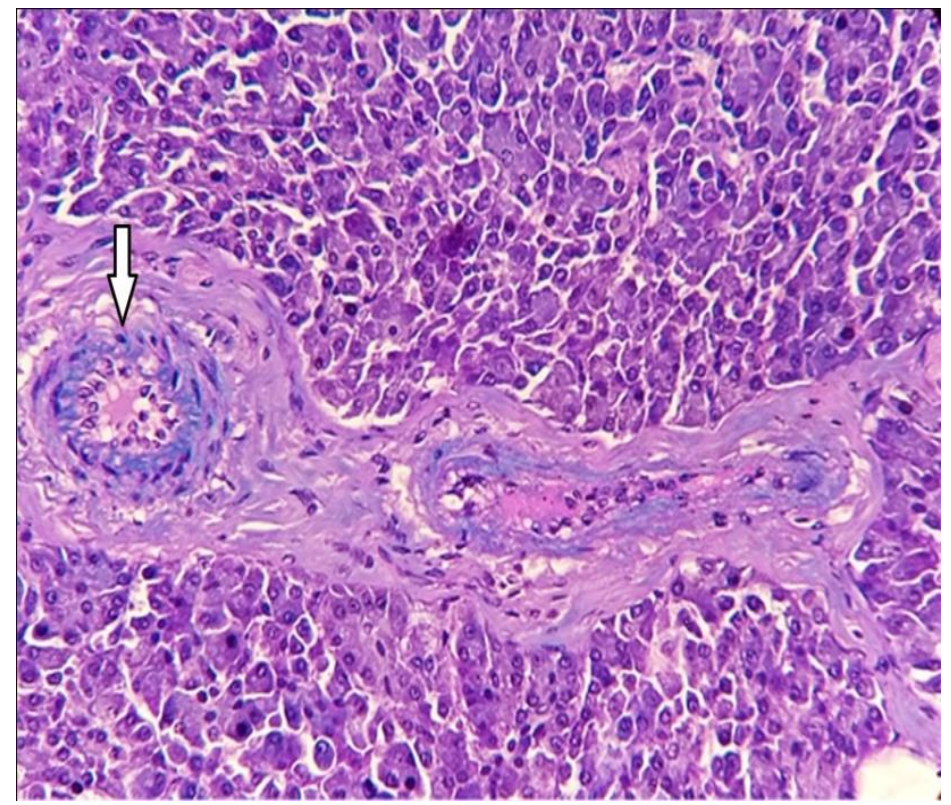

\section{Enzyme Histochemistry}

Mild to moderate acid phosphatase activity was observed in acinar cells and epithelial cells of pancreatic ducts in both the pigs as stated by Prakash et al., (2014) and Divya et al., (2015) in Madras red sheep and buffalo respectively.

The epithelium of intralobular and interlobular ducts, glands in the main duct and acinar cells showed moderate alkaline phosphatase activity. Similar observations were also noted by Divya et al., (2015) in Madras red sheep and McMinn and Kugler (1961) in mouse and rat. The stroma and islets of Langerhans showed weak alkaline phosphatase reaction as stated by Githens et al., (1980) in rat.

Non-specific esterase activity was mild to moderate in the exocrine and endocrine portions of the pancreas in large white Yorkshire and desi pigs which are similar to the findings of Divya et al., (2015) in buffalo and Prakash et al., (2014) in Madras red sheep.

\section{References}

Bancroft, J. D. and A. Stevens, 1996. Theory and Practice of Histological Techniques. $\quad 4^{\text {th }}$ edn. Churchill Livingstone, Edinburgh, London.

Budipitojo, T., Y. H. Fibrianto and G. T. Mulyani, 2016. The types of endocrine cells in the pancreas of Sunda porcupine (Hystrix javanica). Vet. World, 9: 563567.

Deprem, T., S. K. Tasci, S. A. Bingol, E. K. Sari, S. Aslan and S. Ilhan, 2015. Histological and histochemical studies on the structure of pancreatic ducts of the goose (Anser anser). Turk. J. Vet. Ani. Sci., 39(1): 62-68.

Divya, G., U. Varinder, B. Neelam and G. Anuradha, 2015. Histoenzymic localization in Pancreas of Buffalo during Prenatal life. Ind. J. Vet. Anat., 27(1): 9-11.

Githens S. III., D. R. G. Holmquist, J. F. Whelan and J. R. Ruby, 1980. Characterization of ducts isolated from the pancreas of the rat. J. Cell Biol., 85(1): 122-135. 
Hamodi, H. M., A. A. Abed and A. M. Taha, 2013. Comparative anatomical, histological and histochemical study of the pancreas in two species of birds. Res. Rev. in Bio.Sci, 8(1): 26-34.

Hilling, D., J. K. R. A. Rijkelijkhuizen, H. A. M. Tons, O. T. Terpstra and E. Bouwman, 2009. Amount and distribution of collagen in the pancreas have no effect on porcine islet isolation outcome. Transplant. Proc., 41(1): 326327.

Luna, L.G. 1968. Manual of histological staining methods of the armed forces institute of pathology. $3^{\text {rd }}$ edn. Mc Graw Hill Book Co., New York.
McMinn, R. M. H. and J. H. Kugler, 1961. The glands of the bile and pancreatic ducts: Autoradiographic and histochemical studies. J. Anat., 95(1): 111.

Prakash, P., S. U. Kumary, T. A. Kannan, G. Ramesh and S. H. Basha, 2014. Microanatomy of the Islets of Langerhans in the Pancreas of Madras Red Sheep (Ovis aries). Ind. J. Vet. Anat., 26(1): 40-42.

Singh, D. and A. N. Gupta, 1995. Fibroarchitecture of the pancreas in buffalo. Indian J. Anim. Sci., 65(12): 1315-1316.

\section{How to cite this article:}

Iniyah K., S. Jayachitra, K. Balasundaram and Arulmozhi A. 2018. Histochemistry of Pancreas in Large White Yorkshire and Desi Pigs. Int.J.Curr.Microbiol.App.Sci. 7(06): 3206-3209. doi: https://doi.org/10.20546/ijcmas.2018.706.376 